\title{
Personality Traits as Correlate of Posttraumatic Stress Disorder among Displaced People in Anambra State
}

\author{
Ofojebe Chukwuma Philip, Okoli, Paul Chibuike, Chime Peter Ekpunobi
}

\begin{abstract}
This study investigated the relationship between personality traits using the Big Five personality trait and post traumatic stress disorder among displaced people from select areas of Anambra State. Forty eight (48) participants comprising of 30 males and 18 females selected from three Governments Areas of the State participated in the study. All the participants were recently displaced and suffered huge losses from different tragic occurrences within the country including terrorist attacks and fire disasters. The participants' ages ranged from 26 to 56 years with mean age of 37.7 and standard deviation of 9.1. Posttraumatic Stress Disorders (PKS) and Big Five Inventory (BFI) were used to assess the PTSD and the five dimensions of personality. Cross-sectional survey design was employed while Pearson's Product- moment the area to enhance knowledge and improve management of correlation was used as the appropriate statistics. Five hypotheses were tested on whether PTSD is related to personality traits. The result indicated that only hypothesis 4 which states that "Agreeableness trait of personality would not correlate with PTSD among displaced people", was rejected at $(r=-.393, p<$ .05). The other hypotheses were all accepted. The result was discussed in line with the findings. The researcher recommended that more effort be directed by health workers and therapists to other areas than personality, to unearth the underlying influences on PTSD, for better management. Broader research is recommended in PTSD.
\end{abstract}

Index Terms - Personality traits, posttraumatic stress disorder, and displaced people.

\section{INTRODUCTION}

The idea of traumatic experience as the leading causative factor in the development of PTSD has been rejected by empirical data (Johnson and Thompson, 2008). Epidemiological studies have documented high prevalence rates of exposure to traumatic events in the general population and confirmed that PTSD occurs following a wide range of extreme life events (Kessler, Chiu, Demler, Merikangas, and Walters, 2005). An important factor, is the consistent findings indicating that, though exposure to potentially traumatic events is common, development of PTSD is relatively rare, usually between 5 and $10 \%$ in general population (Lloyd and Turner 2003, Kessler et al., 2005). Clarification of factors responsible for some people developing PTSD while others exposed to similar threatening

\footnotetext{
Ofojebe Chukwuma Philip, Department of Psychology, NnamdiAzikiwe University-Awka Anambra State-Nigeria

Okoli, Paul Chibuike, Department, Department of Internal Medicine ESUT College of Medicine, Enugu State University of Science and Technology, Enugu-Nigeria

Chime Peter Ekpunobi, Department: Department of Internal Medicine ESUT College of Medicine, Enugu State University of Science and Technology, Enugu-Nigeria.
}

events do not may help us to answer the longstanding question whether trauma reactions are the consequence of personality defects, or if psycho-trauma largely overshadows the entire personality.

Previous studies have identified some pre-trauma and post-trauma variables of great importance in addition to the traumatic event itself, such as genetic factors, perceived lack of parental care, past history of trauma and psychological problems, unhealthy life styles, personality traits, intelligence, as well as post-trauma support, beliefs, expectations and attributions (Yehuda and McFarlane, 1995, Jakovljević, 2012). It has been shown that individual differences in personality traits, play an important role in the development, outcome and formation of specific symptoms of PTSD (Fauerbach, Lawrence, Schmidt, Munster, Costa, 2000, Gil, 2005, Engelhard and van den Hout, 2007, Miller and Resick, 2007, Wolf , Miller, Krueger, Lyons, Tsuang, and Koenen, 2012).

Personality traits are traditionally conceptualized as dimensions of individual differences in tendencies to show consistent patterns of thoughts, feelings, and actions across developmental periods and contexts (McCrae \& Costa 2003). Advances in the field of personality have put more emphasis on the interface between personality and psychopathology, including PTSD (Krueger, 2006). This dimensional model assumes there are individual differences in personality structure regarding their vulnerability or resilience to mental distress, in this case PTSD. Personality has been linked to affective dispositions, structural and biochemical systems in the brain with a role incausing psychopathology.Treatment options should be focused on helping individuals use their personalitybased resources and strengths to increase personal wellbeing and restore resilience.

Most personality theories can be grouped into one of four classes: psychoanalytic, trait, social learning, and humanistic. Trait theories of personality imply personality is biologically based, whereas state theories such as Bandura's (1977) Social Learning Theory emphasize the role of nurture and environmental influence. Sigmund Freud'spsychodynamic theory of personality assumes there is an interaction between nature (innate instincts) and nurture (parental influences) (McLeod, 2014). Humanistic theories stress our positive nature, our push toward growth and self- actualization. Their emphasis is on the "here and now" rather than on events in early childhood that may have shaped the individual's personality. In an attempt to explain the relationshipbetween personality and PTSD, trait theory of personality known as the "five factor" or "big five" model has been chosen for this study. 
The five-factor model of personality (FFM) (Costa and McCrae, 1992) is the most popular structural personality model, confirmed across virtually all cultures and fairly stable over time (McCrae and Costa, 2003). In addition, research suggests that the Big Five traits have a physiological and genetic basis and the heritability of its dimensions appears to be quite substantial (Bouchard and McGue, 2003; Ožura, Ihan, and Musek, 2012). The dimensions composing the 5-factor model are Neuroticism, Extraversion, Agreeableness, Conscientiousness and Openness to Experience, which encompass 30 lower-order facets.

In the recent years, there seem to be a surge of violence and insurgency in Nigeria, especially the North-east zone. Some of the major instances include: the hostage of Chibok's school girls since April 2014, and series of bombings in northern Nigeria on May 29 ${ }^{\text {th }}, 2011$ (e.g. bombing besides women development centre in Abuja), August $26^{\text {th }}, 2011$ bombing of United Nations (UN) headquarters in Abuja, May 21, and November 10, 2014 bombing in Jos, Ezea - Ezillo crisis in Ebonyi State between late January to early April, 2010, Jos religious crisis of 2006 / 2007, Aguleri - Umuleri communal war in Anambra state, several fire incidents across the country, of which Lagos State alone was reported to have recorded 1662 fire incidents in 2014 and others. All these go to show the extent of traumatic events going on in the country. Not only in Nigeria but across the globe, terrorist attacks have led to loss of lives and properties of loved ones and have displaced very many people leaving them in traumatic condition. For example September $11^{\text {th }} 2001$ terrorist attack on United States (US), September 19 ${ }^{\text {th }}, 2011$ Guatemala earthquake, September $9^{\text {th }}, 2011$ Vancover earthquake in Canada region, September $2^{\text {nd }}, 2011$ Santiego-Delestro earthquake in Argentina, May $19^{\text {th }} 2011$ Western Turkey earthquake, March 11 $1^{\text {th }}, 2011$ Tohoku earthquake and tsunami in Japan, 25 ${ }^{\text {th }}$ October, 2010 Indonesian tsunami, $27^{\text {th }}$ February, 2010 Chilean tsunami, Civil Unrest from $18^{\text {th }}$ December $2010-18^{\text {th }}$ September, 2011, the ISIS and ISIL attacks are still ongoing in Tunisia, Egypt, Yemen, Libya, Syria, Jordan, Iraq and the most recent xenophobic attacks in South Africa which started in April 2015, Nepal earthquake in April 2015 etc. These reported events suggest that the overall prevalence of exposure to traumatic events worldwide may be even higher than reported and this might increase the rate of displaced persons.

The aftermath of these events such as war, violence or natural disasters like flood,is often accompanied by psychological symptoms that persist in some people, long after the stressful events are over. According to the DSM -5, Post-traumatic stress disorder (PTSD) is a severe anxiety disorder that is brought on by exposure to extreme physical harm or danger. Near-death experiences, torture or extreme bodily harm, disaster, physical or sexual assault, or psychological damage and affliction can all lead to PTSD. People who directly lived through or were witnesses to such events can develop the disorder (APA, 2013). In other words, the likelihood of developing PTSD is increased if the traumatic event involved danger or violence from other people such as assault, rape, wartime experiences and flood (Yehuda and Le Deoux, 2007). Traumatic event is defined as "exposure to actual or threatened death, serious injury, or sexual violence" (APA, 2013). It connotes an unpleasant or disturbing experience that causes physical and psychological distress or harm, and is perceived and experienced as a threat to one's safety or to the stability of one's world. The symptoms produced by such exposure included recurrent dreams or recollections of the event, feelings that the traumatic event is recurring with intense psychological distress. These nightmares, recollections, or flashback episodes can lead the person to avoid thinking about the traumatic event which often results in diminished interest in social activities, feelings of detachment from others, suppressed emotional feelings and a sense that the future is bleak and empty (Brewin, 2011). Psychological symptoms of PTSD include difficulty in falling asleep, irritability, outburst of anger, difficulty in concentrating and heightened reactions to sudden noise and movements. This apt description indicates that, people with PTSD have impaired mental health functioning. They also tend to generally have poor health conditions (Zayfart, 2002).

Personality traits are conceptualized as dimensions of individual differences in tendencies to show consistent patterns of thoughts, feelings, and actions across events, developmental periods and contexts (McCrea and Costa, 2003). Advances in the field of personality have put more emphasis on the interface between personality and psychopathology, including PTSD Wolf, Miller, Harrington, and Reardon, (2012). Thus neuroticism, extraversion, and openness to experience (NEO) dimensional model proposed by Costa and McCrae (1978); assumed that there are individual differences in personality structure regarding their vulnerability or resilience to mental illness. In a cross-sectional study conducted on holocaust survivors, Brodaty, (2004) found that, neuroticism was significant to the development of PTSD. In another development, Bennett, (2002) studied myocardial infarction patients and found that; neuroticism predicted the development of PTSD symptoms three months later. Similarly, McFarlane, (1992) found that, neuroticism predicted the progression of PTSD from intrusive symptoms in the acute aftermath of trauma to chronic disorder over three years later. Another study by Cox, (2004), showed that among individuals exposed to trauma, neuroticism is a significant predictor of PTSD even after controlling a range of other important risk factors such as gender, pre-existing anxiety and depression.

\section{STATEMENT OF THE PROBLEM}

Despite the findings of various mental health implications of war, flood, communal crisis, violence or other natural disasters by different scholars (Janice, Hughes and Gomen, 2001; Barrows and Finger, 2008; Tsutsumi, Izutsu, Poudyal, Kato and Marui; 2008; Lawani, Ihenyen, Igberase and Omoaregbe, 2009) much empirical work from the researcher's observation are yet to be done to investigate possible relationship between personality traits and posttraumatic stress disorder especially among displaced people in Nigeria. PTSD has been found to be the common psychological disorder following traumatic experience (Caffo and Blaise, 2003). 
A study by Obiora, Muideen, Ahamefule, Richard, and Onwukwe, (2011), using roadtraffic accident victims $(n=150)$, at National Orthopaedic Hospital Enugu, Nigeria indicates $26.7 \%$ of PTSD prevalence among the studied group. In another study using hospitalized Nigerian army veterans evacuated from the Liberian and Sierra-Leonean wars, Okulate and Jones, (2006), found the prevalence rate for PTSD to be $22 \%$ and survivor guilt was found in $38 \%$ of the responders. Although the sample studied was specific, PTSD might be quite common and probably undetected among Nigerians especially with the recent upsurge in terrorist activities and violence in the country.

Knowledge of the relationship between Personality and PTSD is therefore perceived to be pertinent as it will provide clearer guide and direction in the diagnosis and psychotherapeutic management of PTSD clients. The overall findings from literature suggest that neuroticism accounts for the risk of developing PTSD symptoms. But as for other personality dimensions, namely: extraversion, openness to experience, Conscientiousness, and agreeableness; the results are inconsistent and further research is needed so as to bridge the gap in knowledge, and enhance management of PTSD patients, hence, this study is being carried out.

\section{PURPOSE OF THIS STUDY}

The major purpose of this study is to examine the relationship between personality traits and post-traumatic stress disorder (PTSD) among displaced people. In specific terms, the study intends to find out:

1. The extent to which neuroticism is related with PTSD among displaced people

2. The extent to which extraversion correlates with PTSD among displaced people.

3. The extent to which openness to experience correlates with PTSD among displaced people

4. The extent to which Conscientiousness correlates with PTSD among people

5. The extent to which Agreeableness correlates with PTSD among displaced people

\section{Operational definition of key study variables}

Personality traits: Personality traits are conceptualized as dimensions of individual differences in tendencies to show consistent patterns of thoughts, feelings, and actions across events, developmental periods and contexts. This is measured by the use of Big Five Personality Inventory (BFI).

Posttraumatic Stress Disorder: PTSD: for the purpose of this study, PTSD is defined as traumatised people with severe anxiety disorder that is brought on by exposure to extreme physical harm or danger, as measured by PKS instrument based on DSM-IV-TR criteria.

Displaced people: These are people who lost loved ones and/or great deal of their properties in and forcefully left their initial places living and joined their relatives or returned to places of origin as a result terror attacks and fire incidents in the country. This is as opposed to those who are in camps, because none existed in the State as at the time of this research.

\section{Hypotheses}

The following hypotheses were postulated to guide this study. The tenability of the hypotheses will be tested at 0.05 Alpha level of significance.

1. Openness to experience trait would not correlate with PTSD among displaced people.

2. Conscientiousness trait would not correlate with PTSD among displaced people.

3. Extroversion trait would not correlate with PTSD among displaced people.

4. Agreeableness trait would not correlate with PTSD among displaced people.

5. Neuroticism trait would not correlate with PTSD among displaced people.

\section{METHOD}

\section{Participants}

A total of 48 participants comprising of 30 males and 18 females were drawn from three Local Governments Areas of Aguata, Anaocha, and Orumba North all in Anambra State. All the participants were recently displaced and traumatized either by recent fire incidents at Balogun Market and Kirikiri area ofLagos State, Nigeria in January 2015, and survivors of recent terrorist attacks and bombings in the North specially the ones occurring between October and December 2014 in Kano and Jos. The participants were located through the support of their various community leaders and religious heads.

They have all suffered loss of major means of livelihood, place of abode or loss of loved ones in terror attacks or fire incidents. All of them have returned home to start life afresh but still not knowing where to start or how to do so, as they lost most of their earnings to terror or fire incident.

The participants were within the age range of 26 to 56 years with mean age of 37.7 and standard deviation of 9.1. The reason for choosing people of that age range was to increase internal validity of the research by selecting people who were living independently before the tragic event that led to their displacement.

Thirty eight (38) of the participants are married while ten (10) are single.13of the participants had only secondary school education, 4 of them had Ordinary National Diploma, 9 participants had Higher National Diploma, while 22 other participants had First School leaving Certificate, However, all the participants could read and understand English language.

\section{Instrument}

The following instruments were used in this study to collect data from selected

participants, they are: Big Five Inventory (BFI) and Posttraumatic Stress Disorder (PKS). The use of PKS instead of the new CAPS-5 was as a result of difficulty the researcher had in assessing the new version because it is not yet available in the Country.

\section{Big Five Inventory (BFI)}

The Big five personality inventory was developed by John, Donahue and Kentle (1991). The Big five inventory (BFI) is a 44- item inventory developed to assess the five dimensions of personality (John, Donahue and Kentle, 1991). The items are 
structured to reflect the five domains of personality traits, namely: Openness to experience, Conscientiousness, Extraversion, Agreeableness and Neuroticism. These domains are sub-grouped into facets, and the facets contain different number of items. The scale has a Cronbach Alpha reliability of .80 and 3 months test-retest reliability of .85 as obtained by Umeh (2004). Costa and Mcrae (1992) and Goldberg (1992) obtained a convergent validity coefficients of .75 and .85 respectively. While locally in Nigeria Umeh (2004) used it together with the University Maladjustment Scale to measure the impact of personality characteristics on University adjustment, (Kleinmnuntz, 1961) using it against College Maladjustment scale, obtained the following divergent validity: Extraversion .05, Agreeableness .13, Conscientiousness .11, Neuroticism .39, and Openness .24. In South-East Nigeria Udo (2011) conducted confirmatory factor analysis on the big five inventory. The result confirmed the five big factors in the scale.

\section{Posttruamatic Stress Disorders (Pks)}

PKS is a standardized psychological assessment instrument developed by Keane, Malloy and Fairbanks (1984) and validated for use with Nigerian samples by Ayonuwe (2003). The instrument is a 46 item inventory that is one of the six additional MMPI-2 supplementary scales. These are scales specially developed by analyzing the content of MMPI-2 items (Butcher, Dahl, Storm, Graham, Tellegan and Kaemmer, 1989) and regrouping them to measure specific personality behavioural characteristics that are distinct from the clinical scales of MMPI-2. Keane et al (1984) obtained Cronbach Alpha reliability coefficients of .50 for men and .87 for women and a test -retest reliability coefficients of .86 for men and .89 for women. , Keane et al (1984) obtained a concurrent validity coefficient of .80 by correlating the PKS version of MMPI - 1 with that of MMPI -2. By correlating PKS with SCL -90 Somatisation scale (Derogatis et al, 1977) and Psychophysiological Symptom Checklist (PSC) (Omoluabi, 1987), Ayonuwe (2003) obtained concurrent validity coefficients of .97 and .91 respectively. The Nigerian norms or mean scores are the bases for interpreting the scores of the client. Scores equal or higher than the norms indicate that the client manifest post traumatic stress disorder while scores lower than the norm indicate the absence of post traumatic stress disorder,

A score of I point is given for each scoring response. The following are the expected scores for the items:

a. 1 point for each " $F$ " shaded/marked in items: $1,2,3,14,19,24,26,29$.

b. 1 point for each " $T$ " shaded / marked in the remaining 38 items: 4-13, 15-18, 20-23, 25, 27, 28, 30-46.

c. Final score is obtained by adding together the number of "F" and "T" items correctly marked to obtain the total test score for PKS. Separate norm have been reported for male and female Nigerian samples as follows: Males $=14.38$, females $=12.44$ (Ayonuwe, 2003) .

In this study, the Nigerian norm for male and female samples was the basis for interpretation of the scores of the participants. Scores equal to or higher than the norms indicate that the victim manifests PTSD while scores lower than the norm indicates the absence of PTSD

\section{PROCEDURE}

The participants were identified in small groups through the help of church leaders where they gathered for some social support. This was occasioned by the call by the catholic Diocese of Awka which covers seven (7) Government areas of the State for churches to organise material support for our brethren displaced from violent clashes in the country. The collected items were then distributed to the affected individuals who were notified through announcements in churches. The researcher then took permission from the organisers to conduct the research among those who responded to the announcement. The researcher was able to effectively cover three government areas because the event took place simultaneously in some places. Some others were contacted in their family homes with the help of community leaders who introduced the researcher to them.

The tests were administered on those who were visited in their family homes, after commiserating with them. The purpose of the research was explained to them. Their security and confidentiality was assured and consent form was also clearly explained before it was filled by them.

Those met in groups were also commiserated with and encouraged not to lose hope in life. After commiserating with them over their misfortune by the organisers, the researcher took permission and explained the reason and purpose of this research to them. Those who voluntarily accepted to participate were given the consent form to fill. The content of the form was clearly explained to them in a way they could understand. Those who willingly filled the consent form were then administered first with the Big Five Inventory (BFI). Then, Post Traumatic Stress disorder scale (PKS) was also administered on them while all present shared all items provided by the donor agencies.

A total of 48 properly filled instruments of both BFI and PKS were returned. This comprised of 30 male and 18 female participants.

Inclusion Criteria

1. Adults who had already established themselves with good means of livelihood but lost those means as a result of terrorist activities or fire incidents in the country and have relocated to their villages to try starting life afresh.

2. Those who experienced severe physical/emotional harm as a result of the above incidents in the country.

3. Those who met the above specifications and are lettered enough, with both physical and emotional stability to read and understand the instrument as to complete them adequately.

Those who did meet the above conditions were not included.

\section{Design/Statistics}

Cross-sectional survey design was employed while Pearson's Product- moment correlation was used as the appropriate statistics. 


\section{RESULT}

Table 1: Table of correlations on Openness to experience and with PTSD among displaced participants

Posttraumatic Extraversion Agreeableness

stress

disorder

\begin{tabular}{|c|c|c|}
\hline Conscientiousn & Neurotici & Openness \\
\hline ess & $\mathrm{sm}$ & to \\
\hline
\end{tabular}

\begin{tabular}{cccccccc}
$\begin{array}{c}\text { Openness } \\
\text { experience }\end{array}$ & to $\begin{array}{c}\text { Pearson } \\
\text { Correlation }\end{array}$ & -.165 & .132 & .211 & .202 & .213 & 1 \\
$\begin{array}{c}\text { Sig. } \\
(2-\text {-tailed }) \\
\mathrm{N}\end{array}$ & .263 & .373 & .150 & .169 & .146 \\
& 48 & 48 & 48 & 48 & 48 & 48 \\
\hline
\end{tabular}

The above hypothesis was accepted at $(\mathrm{r}=-.165, \mathrm{p}<.05)$. This means that there was no relation between openness to experience and posttraumatic stress disorder in displaced participants.

Table2:Table of correlations onConscientiousness and PTSD among displaced participants

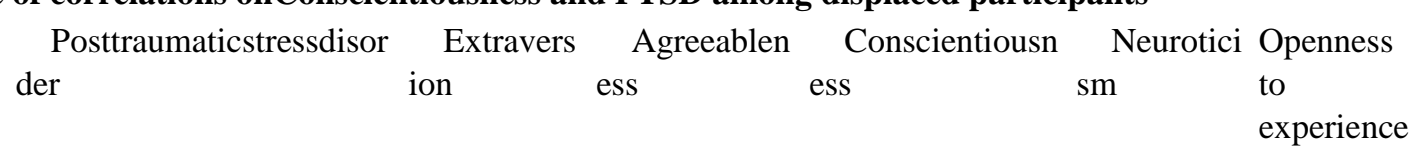

\begin{tabular}{|c|c|c|c|c|c|c|c|}
\hline \multirow{4}{*}{$\begin{array}{l}\text { conscientiousn } \\
\text { ess }\end{array}$} & Pearson & -.095 & -.018 & .146 & 1 & .274 & .202 \\
\hline & Correlation & & & & & & \\
\hline & $\begin{array}{c}\text { Sig. } \\
\text { (2-tailed) }\end{array}$ & .519 & .905 & .322 & & .060 & .169 \\
\hline & $\mathrm{N}$ & 48 & 48 & 48 & 48 & 48 & 48 \\
\hline
\end{tabular}

The statistic revealed that this was accepted at $(\mathrm{r}=-.095, \mathrm{p}<.05)$. It implied that conscientiousness did not relate with posttraumatic stress disorder amongst the participants.

Table3: Table of correlations on Extroversion and PTSD among displaced participants.

Posttraumatic Extraversion Agreeableness Conscientiousness Neuroticism Openness stress disorder

to

experience

$\begin{array}{cccccccc}\text { Extraversion } & \begin{array}{c}\text { Pearson } \\ \text { Correlation } \\ \text { Sig. }\end{array} & .042 & 1 & -.064 & -.018 & -.003 & .132 \\ & & .778 & & .667 & .905 & .982 & .373 \\ & (2-\text { tailed }) & & & & 48 & 48 & 48\end{array}$

The hypothesis was also accepted at $(\mathrm{r}=.042, \mathrm{p}<.05)$, showing that extraversion and posttraumatic stress disorder had no relation amongst the participants in this study. 
Personality Traits as Correlate of Posttraumatic Stress Disorder among Displaced People in Anambra State

Table 4: Table of correlations onAgreeableness and PTSD among displaced participants

Posttraumatic Extraversion Agreeableness Conscientiousness Neuroticism Openness stress

disorder

to experience

\begin{tabular}{|c|c|c|c|c|c|c|c|}
\hline \multirow[t]{3}{*}{ Agreeableness } & $\begin{array}{c}\text { Pearson } \\
\text { Correlation }\end{array}$ & $-.393^{* *}$ & -.064 & 1 & .146 & .112 & .211 \\
\hline & $\begin{array}{c}\text { Sig. } \\
\text { (2-tailed) }\end{array}$ & .006 & .667 & & .322 & .450 & .150 \\
\hline & $\mathrm{N}$ & 48 & 48 & 48 & 48 & 48 & 48 \\
\hline
\end{tabular}

The above statistics that the hypothesis was rejected at $(\mathrm{r}=-.393, \mathrm{p}<.05)$. The result revealed a moderate negative correlation, which means that agreeableness negatively related with posttraumatic stress disorder among displaced participants.

Table 5: Table of correlations on Neuroticism and PTSD among displaced participants

$\begin{array}{ccccccc}\text { Neuroticism } & \begin{array}{c}\text { Pearson } \\ \text { Correlation }\end{array} & -.058 & -.003 & .112 & .274 & 1\end{array}$

Correlation

$\begin{array}{lllllll}\text { Sig. (2-tailed) } & .695 & .982 & .450 & .060 & & .146 \\ \mathrm{~N} & 48 & 48 & 48 & 48 & 48 & 48\end{array}$

This hypothesis was also accepted at $(\mathrm{r}=-.058, \mathrm{p}<.05)$,implying that neuroticism does notcorrelatewith posttraumatic stress disorder among the participants.

\section{DISCUSSION}

Hypothesis 1 which stated that openness to experience will not correlate with PTSD among displaced participants was accepted. This finding showed that openness to experience did not correlate with posttraumatic stress disorder amongst displaced people in Anambra state $(\mathrm{r}=-.165$, $\mathrm{p}<.05$ ). As such it implies that openness to experience which is characterized by active imagination, aesthetic sensitivity, attentiveness to feelings, preference for variety, and intellectual curiosity (Costa and McCrae, 2000) did not correlate with posttraumatic stress disorder. This finding is supported by some previous studies that found Openness to experience as a protective factor at the individual level in the face of potentially traumatic events. (Lee-Baggley, Preece, and DeLongis, 2005; Oswald, 2006; Williams, 2009).

This result also agreed with Paris (2000) who found that openness to experience does not influence the development of PTSD among participants. This result went further to confirm the traits theory explained in chapter 2 of this study about openness to experience. Culturally speaking, Anambra people are creative and cherish adventures, features that are seen in individual with openness to experience. In view of this explanation the displaced participants in Anambra could easily adapt to the new situation and quickly create other means of survival despite the traumatic experiences. Udoh (2011) affirmed in his study on Big-Five Personality predictors of Relative Longevity of people of Anambra State that openness to experience did not correlate with Relative Longevity. This by implication could mean that Anambra people are intellectually curious and business sensitive which make them more resistance to PTSD.
Hypothesis 2 which states that conscientiousness will not correlate with PTSD among displaced participants was accepted $(\mathrm{r}=-.095, \mathrm{p}<.05)$. This result showed that conscientiousness did not correlate with PTSD among displaced participants. Conscientiousness is characterized by persistence, industriousness and organization (Marshell, Wortman, Vickers, Kusulas\&Hervig, 1994). Those who scored high on this trait are more organized and purposeful, in the same vein Udoh (2011) found no correlation between conscientiousness and relative longevity of Anambra people. This finding is also in consonant with the findings of Weiss and Costa (2005), Willson, De Leon, Biennias, Evans and Bennett (2004). They found that conscientiousness has no significant correlation with mortality. The explanation for this finding could be based on the fact that these participants exhibit high sense of industrious and persistence which are cultural characteristics of Anambra people in general. It should be pertinent to note that cultural differences shape and determines the manifestation of psychopathology. The result of this study revealed that individuals with conscientiousness trait can resist the development PTSD even in the face of traumatic event like displacement due to natural or man-made factors.

Hypothesis 3which states that Extroversion will not correlate with PTSD among displaced participants in Anambra state was accepted $(\mathrm{r}=.042, \mathrm{p}<.05)$ extraversion is characterized by sociability, assertiveness, emotional expressiveness and excitability. People who are high on extraversion are often described as being outgoing and talkative, while, those low in this trait are described as quiet and reserved (Miller, 2003). In one study on the differential susceptibility to affective state of sexually abused children, 
extraverts showed a more positive mood (Morris and Reilly, 2003). This finding suggests that individuals who are high on extraversion were engaging in a form of mood repair and are less likely to experience anxiety over negative feedback. In another study, Van and Jones (2001) examined data from a large British birth cohort $(n=5362)$. At age 16 , individuals from this cohort were asked to complete a personality inventory, and were observed through adulthood. Live rates of schizophrenia at age 43 were strongly related to lower level of extraversion at age 16, whereas high level of extraversion actually reduced overall risk, possibly acting as a protective factor. Findings across studies on resiliency after adverse life experiences suggested that individuals who are high on extraversion are likely to develop a positive self- perception, optimism, and a sense of meaning to life while, those who are low on extraversion tend to respond negatively after a life threatening event and thus, are vulnerable to PTSD. Hence, Kessler (2001) argued that an individual response to stress is often a function of the level of extraversion. The finding of this study is in contrast with the finding of (Eriega, Isukwem, Ojo and Williams, 2014) on personality traits and demographic factors as correlates of PTSD among flood victims $(n=300)$ they found that extraversion influenced the development of PTSD among their participants.

Hypothesis 4 which states that Agreeableness will not correlate with PTSD among displaced participants was rejected at $(r=-.393, p<.05)$. From the result of the analysis it showed that agreeableness negatively correlated with posttraumatic stress disorder amongst displaced participants, This negative correlation means that the more the person's tendency to act in a cooperative, unselfish manner or its inclination toward interpersonal trust and consideration of others, the less traumatized he becomes after experiencing threatening situation such as natural or man-made disaster. Because agreeable individuals usually strive for cooperation rather than competition and it makes them less vulnerable to posttraumatic stress disorder.

Furthermore, the result of this study which showed that agreeableness have a negative correlation with posttraumatic stress disorder was in line with the finding of the study (Willson, et al, 2004) which revealed that agreeableness had no significant correlation with morality. Weiss and Costa, (2005) found in their study that higher neuroticism and lower agreeableness were related to increase morality. From the foregoing it could be deduced that such trait as agreeableness could have helped the participants of this study in their effort to survive against the challenges of being displaced and its consequences.

Hypothesis 5: which states that neuroticism will not correlate with PTSD among displaced participants was accepted ( $r=.058)$ This result does not agree with Paris (2000) that, neuroticism describes a tendency toreact with strong emotion to adverse events while, individuals who are high on this dimension are more prone to stress because their responses are more rapid, more intense and slower to return to baseline. Conversely, those who are low on the trait of neuroticism could "shake off stressful events. In addition, findings by Lauterbach and Vrana (2001), showed that, neuroticism often exaggerates the impact of the event. For example, when under stress, people respond in habitual ways that is, people scoring high in neuroticism might be easily predisposed to PTSD as they could become anxious, nervous, and depressed. This result implies that neuroticism does not correlatewith PTSD, which simply means that neurotic individual may not necessary have posttraumatic stress disorderthis is contrary with the findings of Eriega, Isukwem, Ojo and Williams (2014)that neuroticism influenced posttraumatic stress disorder while, openness to experience did not.

The reason for this result could be the cushioning effectof the significant others from whom the participants were taking shelter during the time of thus research. The support of these significant others could have given them some form of hope and reduced their anxiety.

\section{CONCLUSION}

The study was purposely to investigate the correlates of personality traits and posttraumatic stress disorder among displaced victim in selected localities in Anambra. The study found that among the five factors, it was onlyagreeableness that significantly correlated with PTSD, however it correlated negatively. This indicates that according to this research, personality trait is not a major vulnerability factor in development of posttraumatic stress disorder.

\section{RECOMMENDATIONS}

Following the findings of this study, the researcher presents the following recommendation:

Extended study involving more states and wider range of displaced people in order to increase the generalization validity of the study should be further pursued by other researchers.

Psychotherapists, psychologists, counsellors and other health care providers should look beyond personality factors in unearthing the predisposing and vulnerability factors underlying PTSD.

\section{Limitations of the study}

This study used people of Anambra state within a few selected localities this participants were those who were displaced. However the result should be viewed within the context of the limitations posed by the method and sampling size.

The research participants were all those who were displaced from places they have been staying and earning their living for a long time, but they had some form of significant others, in form of relatives who were at least providing shelter for them at the time of research. They were not encamped in one location, which the researcher believes would have made their situation more deplorable and perhaps affected the outcome of this research.

Compliance with Ethical Standards Conflict of interest:

All authors declare that they have no conflict of interest. All participants filled the consent form to declare their free will to participate in the study. Again, this study was not funded by any person, group or organization. 


\section{REFERENCES}

[1] American Psychiatric Association (2013): Diagnostic and Statistical Manual of Mental Disorders, 5th ed. Washington, DC: American Psychiatric Press.

[2] Barrows, J. Finger, R. (2008). Human trafficking and the health care professional. Southern Medical Journal 101; Number 5, 521 - 524

[3] Ayonuwe, T. M. (2003). Assessment and management of post-traumatic stress reaction among bomb blast victims. Unpublished M.Sc Research Project, Department of Psychology, University of Lagos.

[4] Bennett, P., Owen, R., Koutsakis, S., \& Bisson, J. (2002).Personality, social context and cognitive predictors of post-traumatic stress disorder in myocardial infarction patients.Psychology and Health, 17, 489-500.

[5] Bouchard, T Jr, \& McGue M,(2003) Genetic and environmental influences on human psychological differences. JNeurobiol; 54:4-45.

[6] Bouton, M., \& Swartzentruber, D. (1991).Sources of relapse after extinction in Pavlovian and instrumental learning. Clinical Psychology Review, 11, 123-140.

[7] Bramsen I, Dirkzwager J, \& van der Ploeg H, (2000) Predeployment personality traits and exposure to trauma as predictors of posttraumatic stress symptoms: a prospective study of former peacekeepers. Am J Psychiatry; 157:1115-9.

[8] Breslau N, Davis G, Andreski P, \& Peterson E,(1991) Traumatic events and posttraumatic stress disorder in an urban population of young adults. Arch Gen Psychiatry; 48:216-222.

[9] Brewin, C., \& Beaton, A. (2002). Thought suppression, intelligence, and working memory capacity. Behaviour Research and Therapy, 40, 923-930

[10] Brewin, C., Dalgleish, T., \& Joseph, S. (1996). A dual representation theory of post-traumatic stress disorder. Psychological Review, 103 , 670-686.

[11] Brewin, C., Andrews, B. \& Rose, S. (2003). Diagnostic overlap between acute stress disorder and PTSD in victims of violent crime.American journal, of psychiatry, 160, 783 - 795.

[12] Brewin C., (2011). Walking the line in defining PTSD: Comprehensiveness versus core features. In Stein DJ, Friedman MJ \& Blanco C (eds): Post-traumatic Stress Disorder, 35-37. Wiley-Blackwell, Oxford.

[13] Brodaty, H., Joffe, C., Luscombe, G., \& Thompson, C. (2004) Vulnerability to Posttraumatic Stress Disorder and Psychological mobility in aged Holocaust Survivors. International Journal of Geriatric Psychiatry. 19, 968-979.

[14] Brown, R., \& Kulik, J. (1977). Flashbulb memories. Cognition, 5, 73-99.

[15] Butcher, J., Dahlstrom, W., Graham, J., Tellegen, A. \& Kaemmer, B. (1989). The Minnesota multiphasic personality inventory-2 (MMPI-2): Manual for administration and scoring. Minneapolis, MN: University of Minnesota Press.

[16] Caffo, E., \& Belaise, C. (2003).Psychological aspects of traumatic injury in children and adolescents. Child and Adolescent Psychiatry, 12 (3): $493-535$.

[17] Cattell, R.. (1965). The scientific analysis of personality. Baltimore: Penguin Books.

[18] Chung, M., Berger Z, Jones R, \& Rudd H,( 2006) Posttraumatic stress disorder and general health problems following myocardial infarction ( Post-MI PTSD ) among older patients: The role of personality. Int J Geriatr Psychiatry; 21:1163-1174.

[19] Chung MC, Berger Z, \& Rudd H, (2007) Comorbidity and personality traits in patients with different levels of posttraumatic stress disorder following myocardial infarction. Psychiatry Res; 152:243-52.

[20] Chung M, Dennis I, Berger Z, Jones R, \& Rudd H, (2011) Posttraumatic stress disorder following myocardial infarction: personality, coping, and trauma exposure characteristics. Int J Psychiatry Med.; 42:393-419.

[21] Chemtob, C., Roitblat, H., Hamada, R., Carlson, J. G., \& Twentyman, C. (1988). A cognitive-action theory of post-traumatic stress disorder. Journal of Anxiety Disorders, 2, 253-275.

[22] Cloninger C, Svrakic D, Przybeck T, (1993) A psychobiological model of temperament and character. Arch Gen Psychiatry; 50:975-90.

[23] Connor, K.. \& Butterfield, M.. (2003).Posttraumatic stress disorder. Focus, 1(3) $247-262$.

[24] Costa, P., \& McCrae, R.. (2000). Professional Manual: Revised NEO Personality Inventory (NEO-PI-R) and NEO Five-Factor Inventory (FFI) professional manual. Lutz, FL: Psychological Assessment Resources, Inc.

[25] Costa, P., \& McCrae, R., (1995). Domains and Facets: Hierarchical Personality Assessment Using the Revised NEO Personality Inventory. Journal of Personality Assessment, 1995,64(1), 21-50 Lawrence
Erlbaum Associates, Inc. Gerontology Research Center National Institute on Aging, NZH Baltimore, MD.

[26] Costa, P., \& McCrae, R., (1992).The five-factor model of personality and its relevance to personality disorders. Journal of Personality Disorders, 6(4), 343-359. https://doi.org/10.1521/pedi.1992.6.4.343

[27] Cox, M.. (2004). Faculty Learning Community Program Director's and Facilitator's Handbook. Oxford, Ohio: Miami University.

[28] Creamer, M., Burgess, P., \& Pattison, P. (1992). Reaction to trauma: a cognitive processing model. Journal of Abnormal Psychology, 101, $452-459$.

[29] Creamer M, Burgess P, \& McFarlane A,(2001) Post-traumatic stress disorder: findings from the Australian National Survey of Mental Health and Well-being. Psychol Med; 31: 1237-47.

[30] Davidson J, Hughes D, Blazer DG, \& George L,(1991) Posttraumatic stress disorder in the community: An epidemiological study. Psychological Medicine; 21:713-721.

[31] Dalgleish, T. (1999). Cognitive theories of posttraumatic stress disorder. In W. Yule (Ed.), Post-traumatic stress disorders: concepts and therapy ( pp. 193-220). Chichester: Wiley.

[32] Derogatis, L.; Lipman, R. \& Covi, L. (1997). SCL-90 Administration, Scoring and Procedures Manual. Baltimore: John Hopkins University School of Medicine, Clinical Psychometrics Research Unit.

[33] Dörfel D, Rabe S, \& Karl A, (2008) Coping Strategies in Daily Life as Protective and Risk Factors for Posttraumatic Stress in Motor Vehicle Accident Survivors. Journal of Loss and Trauma - International Perspectives on Stress \&Coping; 13:422-40.

[34] Ehlers, A., \& Clark, D., (2000).A cognitive model of posttraumatic stress disorder. Behaviour Research and Therapy, 38, 319-345.

[35] Ehlers, A., Hackmann, A., Steil, R., Clohessy, S., Wenninger, K., \& Winter, H. (2002). The nature of intrusive memories after trauma: the warning signal hypothesis. Behaviour Research and Therapy, 40, 995-1002

[36] Ehlers, A., Maercker, A., \& Boos, A. (2000). Posttraumatic stress disorder following political imprisonment: the role of mental defeat, alienation, and perceived permanent change. Journal of Abnormal Psychology, 109, 45-55.

[37] Engelhard I, van den Hout M, (2007) Preexisting neuroticism, subjective stressor severity, and posttraumatic stress in soldiers deployed to Iraq. Can J Psychiatry, 52:505-9.

[38] Eriega E.G, Isukwem, G.C., Ojo T.T. \& Williams A. A., (2014): Personality And Demographic Factors As Correlates Of Posttraumatic Stress Disorder (Ptsd) Among Flood Victims; British Journal of Education Vol.2,No.3, pp. 82-88, July 2014 (www.eajournals.org)

[39] Eysenck, H. J. (1952). The scientific study of personality, cited in McLeod, S.A. (2014).Theories of Personality. Retrieved from http://www.simplypsychology.org/personality-theories.html

[40] Foa, E. B., Ehlers, A., Clark, D. M., Tolin, D. F., \&Orsillo, S. M (1999). The Posttraumatic Cognitions Inventory (PTCI): development and validation. Psychological Assessment, 11, 303-314.

[41] Foa, E. B., Steketee, G., \& Rothbaum, B. O. (1989).Behavioral/cognitive conceptualisation of post-traumatic stress disorder.Behavior Therapy, 20, 155-176.

[42] Foa, E., Riggs, D., Massie, E., \& Yarczower, M. (1995).The impact of fear activation and anger on the efficacy of exposure treatment for posttraumatic stress disorder Behaviour Therapy, 26, 487-499.

[43] Foa, E. B., \& Rothbaum, B. O. (1998). Treating the trauma of rape: cognitive behavioural therapy for PTSD. New York: Guilford Press.

[44] Fauerbach J, Lawrence J, Schmidt C, Munster A, Costa P, (2000) Personality predictors of injury-related posttraumatic stress disorder. J NervMent Dis; 188:510-517

[45] Gelder, M., Harrison, P. \& Cowen, P (2006). Shorter Oxford Textbook of Psychiatry (Fifth edition) Oxford University Press

[46] Gil, S., (2005). Pre-traumatic personality as a predictor of posttraumatic stress disorder among undergraduate students exposed to a terrorist attack: A prospective study in Israel. PersIndDiff ; 39:819-827.

[47] Gillespie, K., Duffy, M., Hackmann, A., \& Clark, D. M. (2002).Community-based cognitive therapy in the treatment of post-traumatic stress disorder following the Omagh bomb. Behaviour Research and Therapy, 40, 345-357.

[48] Goldney, R. D. (2000) Prediction of suicide and attempted suicide. In The International Handbook of Suicide and Attempted Suicide (eds K. Hawton\& K. Van Heeringen: 585 -596. Chichester: Wiley.

[49] Grey, N., Young, K., \& Holmes, E. (2002). Cognitive restructuring within reliving: a treatment for peritraumatic emotional "hotspots" in posttraumatic stress disorder. Behavioural and Cognitive Psychotherapy, 30, 37-56. 
[50] Hendin, H., \& Hass, P. (1991). Suicide and guilt as manifestations of PSTD in Vietnam combat veterans. America Journal of Psychiatry, 148, 586-91.

[51] Holeva, V., \&Tarrier, N. (2001).Personality and peri-traumatic dissociation in the prediction of PTSD in victims of road traffic accidents. Journal of Psychosomatic Research, 51, 687-692.

[52] Holmes, E., Grey, N., \& Young, K. (2003). Intrusive images and "hotspots" of trauma memories in posttraumatic stress disorder: emotions and cognitive themes (submitted for publication).

[53] Hyer L, Braswell L, Albrecht B, Boyd S, Boudewyns P, Talbert S, (1994) Relationship of NEO-PI to personality styles and severity of trauma in chronic PTSD victims. J ClinPsychol; 59:1295-1304

[54] Jacobs, W. J., \& Nadel, L. (1985). Stress induced recovery of fears and phobias. Psychological Review, 92, 512-531.

[55] Jakovljević M,( 1998) Neurobiology of psychotraumatic experience Is PTSD really a unique psychopathological and diagnostic entity? PsychiatrDanub; 10:75-78. 47.

[56] Jakovljević M,(2012) Posttraumatic stress disorder (PTSD): Atailor-made diagnosis for a nage of disenchantment and disillusionment? PsychiatrDanub; 24:238-240.48.

[57] Jakovljević M, Brajković L, Lončar M, čima A,( 2012a) Posttraumatic stress disorders (PTSD) between fallacy and facts: What we know and what we don't know? PsychiatrDanub; 241-245. 49.

[58] Jakovljević M, Brajković L, Jakšić N, Lončar M, AukstMargetić B, \& Lasić D, (2012b) Posttrumatic stress disorders (PTSD) from different perspectives: A transdisciplinary integrative approach. PsychiatrDanub ;246-255

[59] Janoff - Bulman, R., (1985).The aftermath of victimization: rebuilding shattered assumptions. In C.R. Figley (Ed.), Trauma and Its wake: the study and treatment of PTSD. $15-25$. Brunner - Mazel, New York.

[60] Janice, R., Hughes, D., \& Gomen, C. (2001). Sex trafficking of women in United States, links between international and domestic sex industries. Condition Against Trafficking in Women (ATW): North Amherst

[61] John, O., Donahue, E., \& Kentle, R.. (1991). The Big Five Inventory Versions 4a and 54. Berkeley, CA: University of California, Berkeley, Institute of Personality and Social Research.

[62] Johnson H, Thompson A, (2008). The development and maintenance of post-traumatic stress disorder (PTSD) in civilian adult survivors of war trauma and torture: A review. ClinPsychol Rev; 28:36-47.

[63] Johnson, M., \& Multhaup, K. (1992).Emotion and MEM. In S. A, Christianson (Ed.), Handbook of emotion and memory ( pp. 33-66). Hillsdale, NJ: Erlbaum.

[64] Jones, J., \& Barlow, D., (1990).The etiology of posttraumatic stress disorder. Clinical Psychology Review, 10, 299-328.

[65] Keane, T., Malloy, P., \& Fairbank, J., (1984).Empirical development of an MMPI subscale for the assessment of combat-related post-traumatic stress disorder. Journal of Consulting and Clinical Psychology, 52, 888-891.

[66] Kessler, R. (2001). Kessler Psychological Distress Scale (K10). Harvard Medical School, Boston, USA.

[67] Kessler, R., Borges, G., \& Walters, E., (1999).Prevalence and risk factors for lifetime suicidality in the National Comorbidity survey. Archive of General Psychiatry, 56, 617-626.

[68] Kessler, R., Chiu, W., Demler O, Merikangas, K., Walters E., (2005) Prevalence, severity, and comorbidity of 12-month DSM-IV disorders in the National Comorbidity Survey Replication. Arch Gen Psychiatry; 62:617-27.

[69] Kleinmuntz, B. (1961)The College Maladjustment Scale (MT): Norms and Predictive Validity. Research Article: https://doi.org/10.1177/001316446102100432.

[70] Knežević G, Opačić G, Savić D, Priebe S, (2005) Do personality traits predict post-traumatic stress?: a prospective study in civilians experiencing air attacks. Psychol Med; 35:659-663.

[71] Krueger, R., (2006), Personality and Psychopathology. The Guilford Press.

[72] Kunst, M., Bogaerts S, Winkel, F.,: Type D Personality and Posttraumatic Stress Disorder in Victims of Violence: A CrossSectional Exploration. Clin Psychol Psychother; 22:13-22.

[73] Lang, P. J. (1979). A bio-informational theory of emotional imagery. Journal of Psychophysiology, 16, 495-512.

[74] Lauterbach, D \& Vrana, S (2001). The relationship among personality variables, exposure to traumatic events, and severity of posttraumatic stress symptoms. Journal of Traumatic Stress. 14, 29-45

[75] Lawani, A., Ihenyen, O., Igberase, O., \& Omoaregba, J (2009). Mental and behavioural disorders among female victims of human trafficking presenting in a Nigerian Psychiatric Hospital. In Awaritefe, A (Ed). Towards a sane society, Benin City: Roma Publication
[76] Lawrence, J, \& Fauerbach, J, (2003) Personality, coping, chronic stress, social support and PTSD symptoms among adult burn survivors: a path analysis. J Burn Care Rehabil.; 24:63-72.

[77] Layne, C, Warren, J, Watson, P, \& Ahalev A, (2007)., Risk Vulnerability, Resistance, and Resilience: Toward an Integrative Conceptualization of Posttraumatic Adaptation. In Friedman MJ, Keane TM, Resick PA (eds): Handbook of PTSD: Science and Practice, 497-520. The Guilford Press.

[78] Lee-Baggley, D., Preece, M., \&DeLongis, A. (2005).Coping with interpersonal stress: Role of Big Five traits. Journal of Personality, 73, 1141-1180.

[79] Litz, B. T. (1992). Emotional numbing in combat-related post-traumatic stress disorder: a critical review and reformulation. Clinical Psychology Review, 12, 417-432.

[80] Litz, B., \& Keane, T., (1989). Information processing in anxiety disorders: application to the understanding of post-traumatic stress disorder. Clinical Psychology Review, 9, 243-257

[81] Lloyd DA, Turner RJ,(2003) Cumulative adversity and posttraumatic stress disorder: evidence from a diverse community sample of young adults. Am J Orthopsychiatry, 73:381-91

[82] Maia DB, Marmar CR, Henn-Haase C, Nóbrega A, Fiszman A, Marques-Portella C, et al, (2011) Predictors of PTSD symptoms in Brazilian police officers: the synergy of negative affect and peritraumatic dissociation. Rev Bras Psiquiatr; 33:362-366.

[83] Mack, A., \& Rock, I. (1998). Intentional blindness. Cambridge, MA: MIT Press.

[84] McLeod, S.A., (2014). Theories of Personality.http://www/simply psychology.org/personality-theories.html. retrieved: December, 2016.

[85] Marshall, G., Wortman, C., Vickers, R., Kusulas, J., \& Hervig, L., (1994). The five-factor model of personality as a framework for personality-health research. Journal of Personality and Social $\begin{array}{ll}\text { Psychology, } & 67(2), \\ 278-286\end{array}$ https://doi.org/10.1037/0022-3514.67.2.278

[86] McCrae, R. R., Costa, P. T. (2003). Personality in adulthood, a five-factor theory perspective (2nd ed.). New York: Guilford Press.

[87] McCrae, R. R., Costa, P. T. (1992). An introduction to the Five Factor Model and its Applications. Journal of Personality .60(2): 175-215. Doi: 10.1111/j.1467.6494.1992.tb00970.x.PMID1635039.

[88] McFarlane, A., (1992). Avoidance and intrusion in posttraumatic stress disorder. Journal of Nervous and Mental Disease, 180, 439-445.

[89] McFarlane, A., (1988). The longitudinal course of posttraumatic morbidity. Journal of Nervous and mental disease, 176, 30 -9.

[90] Miller, M., Resick, P., (2007) Internalizing and externalizing subtypes in female sexual assault survivors: Implications for the understanding of complex PTSD. BehavTher; 38: 58-71.

[91] Miller, M.W. (2003). Personality and the etiology and expression of PTSD: A three-factor model perspective. Clinical Psychology Science and Practice, 10, 373-393.

[92] Morris, A., Reilly, J., Berry, S. and Ransom, R. (2003). New Zealand National Survey of Crime Victims 2001. Wellington: Ministry of Justice.

[93] Mowrer, O., (1960). Learning theory and behavior. New York: Wiley.Nordqvist C, (2014), What is neuroticism? What causes neurosis?University of West England, Bristol. Retrieved October, 2015.

[94] Obiora, I., Muideen O., Ahamefule O., Uwakwe R., \& Onwukwe J.,(2011); Road traffic accidents and posttraumatic stress disorder in an orthopedic setting in south-eastern Nigeria: a controlled study. Scandinavian Journal of Trauma.BioMed Central.Retrieved October 2015.

[95] Okulate, G., \& Jones, O., (2004).Post-traumatic stress disorder, survivor guilt and substance use - a study of hospitalised Nigerian army veterans. South African Medical Journal 2006; 96 (2): 144.

[96] Omoluabi, P.. (1987). Standardization of the Psychophysiological symptoms checklist. Nigerian Journal of Psychology, 6\&7, (1\&2), 118-128

[97] Orr, S. P., Metzger, L. J., Lasko, N. B., Macklin, M. L., Peri, T., \& Pitman, R. K. (2000). De novo conditioning in trauma-exposed individuals with and without posttraumatic stress disorder. Journal of Abnormal Psychology, 109, 290-298.

[98] Oswald, L., Zandi, P., Nestadt, G., Potash, J., Kalaydijian, A.., Wand, G.. (2006).Relationship between cortisol responses to stress and personality .Neuropsycho pharmacology, 31: 1583-1591. PMID: 16407895.

[99] Ožura A, Ihan A, Musek J,(2012) Can the big five factors of personality predict lymphocyte counts? Psychiatr Danub; 24:66-72.

[100] Paris, J. (2000) Predispositions, personality traits, and posttraumatic stress disorder. Harv Rev Psychiatry 8 (4): 175-83. 
[101] Parslow R, Jorm A, Christensen H, ( 2006) Associations of pre-trauma attributes and trauma exposure with screening positive for PTSD: analysis of a community-based study of 2, 085 young adults. Psychol Med; 36:387-95.

[102] Pillemer, D. B. (1998). Momentous events, vivid memories. Cambridge, MA: Harvard University Press.

[103] Pitman, R., Shalev, A., \& Orr, S., (2000). Posttraumatic stress disorder: emotion, conditioning, and memory. In M. S. Gazzaniga (Ed.), The new cognitive neurosciences (2nd ed.) (1133-1147). Cambridge, MA: MIT Press

[104] Roediger, H. L., \& McDermott, K. B. (1993).Implicit memory in normal human subjects. In H. Spinnler, \& F. Boller (Eds.), Handbook of neuropsychology, vol. 8 (63-131). Amsterdam: Elsevier.

[105] Schnurr P., Friedman M., Rosenberg S, (1993) Premilitary MMPI scores as predictors of combat-related PTSD symptoms. Am J Psychiatry; 150:479- 483.

[106] Sloman, S. A. (1996). The empirical case for two systems of reasoning. Psychological Bulletin, 119, 3-22.

[107] Spitzberg, B., (1999). An analysis of empirical estimates of rape and sexual coercion. Violence and Victims, 14, 241-260.

[108] Talbert, F., Braswell, L., Albrecht, J., Hyer, L., Boudewyns, P., (1993), NEO-PI profiles in PTSD as a function of trauma level. J ClinPsychol; 49: 663-9.

[109] Tellegen A,( 1985.) Structures of mood and personality and their relevance to assessing anxiety with an emphasis on self-report. In Tuma $\mathrm{AH} \&$ Maser JD (eds): Anxiety and the anxiety disorders, 681-706. Erlbaum,

[110] Terr, L. (1990).Too scared to cry. New York: Basic Books.

[111] Tsutsumi, A., Izutsu, T., Poudyal, A.., Kato, S. \& Marui, E. (2008).Survivors of human trafficking in Nepal.Social Science Medicine, 66 (8), 1841-7.

[112] Tulving, E., \& Schacter, D., (1990).Priming and human memory systems. Science, 247(4940), 301-306.

[113] Van Os, J., \& Jones, P., (2001).Neuroticism as a risk factor for schizophrenia. Journal of Psychological Medicine, 31, 1129-1134.

[114] Van der Hart, O., \& Horst, R. (1989).The dissociation theory of Pierre Janet. Journal of Traumatic Stress, 2, 397-412.

[115] Van der Kolk, B., \& Fisler, R. (1995). Dissociation and the fragmentary nature of traumatic memories: overview and exploratory study. Journal of Traumatic Stress, 8, 505-525.

[116] Udo F. (2012). Big five personality predictors of relative longetivity of people of Anambra State. PhD Dissertation presented to the department of Psychology, Nnamdi Azikiwe University, Awka, Anambra State.

[117] Umeh, C. S. (2004). The Impact of personality characteristics on student's adjustment on campus.Unpublished Ph.D Research Monograph, Department of Psychology, University of Lagos.

[118] Van der Kolk, B., \& van der Hart, O. (1991). The intrusive past: the flexibility of memory and the engraving of trauma. American Imago, $48,425-454$.

[119] Weiss, A \& Costa P, (2005). Domain and Facet Personality Predictors of All-Cause Mortality Among Medicare Patients Aged 65 to 100. Psychosomatic Medicine 67(5):724-33. DOI: 10.1097/01.psy.0000181272.58103.18. PubMed

[120] Williams, P., Rau, H., Cribbet, M., \& Gunn, H., (2009).Openness to Experience and stress regulation. Journal of Research in Personality, 43, 777-784.

[121] Williams, P. G. \& Moroz, T. L. (2009). Personality vulnerability to stress-related sleep disruption: Pathways to adverse mental and physical health outcomes. Personality and Individual Differences, 46 , 598-603.

[122] Wilson RS, Mendes de Leon CF, Bennett DA, Bienias JL, Evans DA, (2004).Depressive symptoms and cognitive decline in a community population of older adults. Journal of Neurology, Neurosurgery, and Psychiatry. 2004:75:126-129.

[123] Wolf, EJ, Miller, MW Harrington, KM, Reardon. A,(2012). Personality-based latent classes of posttraumatic psychopathology: personality disorders and the internalizing/externalizing model. J AbnormPsychol; 121:256-62.

[124] Yehuda, R., (2002); Post-Traumatic Stress Disorder. The New England Journal Of Medicine. 346:108-114.

[125] Yehuda, R., \& McFarlane, A., (1995). Conflict between current knowledge about posttraumatic stress disorder and its original conceptual basis. The American Journal of Psychiatry, 152(12), 1705-1713. https://doi.org/10.1176/ajp.152.12.1705

[126] Yehuda R, Engel SM, Brand SR, Seckl J, Marcus SM, Berkowitz GS. (2005). Trans-generational effects of PTSD in babies of mothers exposed to the World Trade Center attacks during pregnancy. Journal of Clinical Endocrinology \& Metabolism. 90:4115-4118.
[127] Yehuda, R., Le Doux, J., (2007). Response Variation following Trauma: A Translational Neuroscience Approach to Understanding. PTSD. Neuron, 56, 19-21.

[128] Yu X, Lau J, Zhang J, Mak W, Choi KC, Lui WS, et al.: Posttraumatic growth and reduced suicidal ideation among adolescentsat month 1 after the Sichuan Earthquake. J Affect Disord 2010; 123:327-331.

[129] Zayfart, C., Becker, C., Unger, D., \& Shearer, D., (2002). Comorbid anxiety disorders in civilians seeking treatment for PTSD. Journal of Traumatic Stress, 15, 31-38. 